\title{
SERÁ QUE AINDA SOMOS CARTESIANOS? BREVE EXCURSO SOBRE A IDEIA DE VIDA
}

\author{
ARE We STILl CARTESIANS? ON THE IDEA OF LIFE
}

\section{EURICO CARVALHO}

Instituto de Filosofia da Universidade do Porto, PORTUGAL

euricodecarvalho@gmail.com

\begin{abstract}
The question that drives us does not seek, in Heideggerian sense, the thoughtless forgetfulness of one historical development, but it only wants to delimit the state of the art concerning the Cartesian world's view. For this purpose, however, it does not go beyond the epistemic horizon of the Philosophy of Biology because this paper will focus on the diagnosis of the "identity crisis" of Biology, whose experimental success should not camouflage its "epistemological depression". Indeed, it is about a science that, between physics and metaphysics, has not yet found its theoretical space. Eventually, it is possible to trace that difficulty back to the modern age and its philosophical roots. Thus, it is necessary an evaluation of the paradigm shift that Descartes has introduced into the order of knowledge, according to which the goal of rational investigation becomes the dominion of nature.
\end{abstract}

Keywords: Descartes $\bullet$ Darwinism $\bullet$ mechanism $\bullet$ neo-Darwinism $\bullet$ vitalism

\section{Introdução}

A interrogação que preside a este ensaio não busca, à maneira heideggeriana, o impensado e o esquecido de um certo desenvolvimento historial, mas há-de apenas delimitar o estado da arte de uma determinada visão do mundo, detectando os seus efeitos, ainda que subterrâneos, num duplo patamar: epistemológico e ético. Quanto à questão enquanto tal, i.e., enquanto horizonte para uma resposta possível, não terá a pretensão de suscitar o aparecimento de uma proposição evidente, ou melhor, inquestionável. Seria desnecessário afirmá-lo, aliás, se não se desse o caso de estarmos perante uma pergunta cujo perfil imediato pode produzir a ilusão de se tratar de um inquérito meramente histórico, ou seja, susceptível de ser resolvido com o concurso da empiria, no sentido estrito do termo. Com tudo isto em mente, tanto nos repugna a ousadia do voo metafísico como a interminável recolha documental. Dando a palavra à mitologia, digamos que Ícaro e Sísifo não são figuras cuja sombra possa tutelar os trilhos da viagem que vamos empreender. Além disso, dado o longo arco temporal que ela engloba, havemos de nos cingir à circum-navegação do essencial, não ultrapassando o domínio epistémico da Filosofia da Biologia. Por isso, não 
poderia ser descurado o diálogo com a Biologia, a qual, no conjunto das ciências de hoje, se tem notabilizado pelo sucesso experimental (talvez incomparável, do ponto de vista dos seus resultados, ${ }^{1}$ com qualquer outra área do conhecimento científico). Paradoxalmente, porém, nela podemos diagnosticar uma "crise de identidade" epistemológica, ${ }^{2}$ porquanto, entre física e metafísica, ainda não encontrou o seu espaço teórico ${ }^{3}$ (Meyer 1981, p.158). É possível remontar esta dificuldade à raiz filosófica da Modernidade: o discurso cartesiano. À mutação paradigmática que ele introduz na ordem do saber corresponde uma reviravolta do significado intrínseco da investigação racional, dando-lhe como destino privilegiado o domínio da Natureza (Descartes 1987, p.102).

\section{A herança cartesiana e os seus obstáculos epistemológicos}

Nas suas Lições sobre a História da Filosofia, Hegel, vendo em Descartes o fundador de um novo pensamento, e de que o Ocidente tem sido o fiel executor testamentário, deixou-se levar pelo entusiasmo: "Aqui estamos em casa e, como o marinheiro após longa errância, podemos finalmente bradar «Terra! »" (cit. por Ferreira 1998, p.438). Ora, de acordo com tal interpretação, havemos de discernir, no projecto cartesiano, dois princípios e um programa: de um lado, subjectividade e autonomia; e, do outro, mecanicismo (rótulo susceptível de resumir o conteúdo programático e o respectivo alcance heurístico). E deste último item, sim, mas sem esquecer os primeiros, teremos de explorar as consequências, que não se esgotam num campo gnosiológico.

O princípio da subjectividade significa a ruptura da harmonia entre pensar e ser. Tal como os gregos a conceberam, numa perspectiva hiper-realista, haveria uma transparência do real, pela sua racionalidade intrínseca, à Ideia. ${ }^{4}$ Com o cogito, contudo, enquanto fundamentum inconcussum, assistimos à redução da verdade — adæquatio intellectu et rei - à certeza de si mesmo. Revela-se o ser como sendo unicamente o pensável, na sua qualidade de evidência intelectual, o que implica, à luz da fundamentação metafísica da ciência moderna (e é este, como sabemos, o desígnio crucial da obra cartesiana), a subsunção da experiência no quadro formal inerente à aplicação da metodologia do cálculo. Daí que, na sequência da assunção da natureza matemática da razão, ${ }^{5}$ estejamos perante um cenário de uma acentuada desontologização dos conceitos, sendo-lhes apenas dado, por numerosos cientistas, um valor operatório, i.e., enquanto instrumentos de "salvação" dos fenómenos. No reino do pragmatismo, não importa o porquê, por ser inviável a sua transformação num programa de investigação experimental, mas o como correspondente ao funcionamento da machina mundi. ${ }^{6}$

Relativamente ao princípio da autonomia, devemos entendê-lo, enquanto recusa 
da exterioridade inerte da autoridade, sob o pano de fundo da experiência interior e originária da liberdade. ${ }^{7}$ Mas como a vontade, contrariamente ao entendimento, não conhece limites, exibe a sua hybris, que nos retira a possibilidade objectiva de questionar o que surge, em termos cartesianos, como inquestionável: o exercício do poder, que se quer sempre maior, sobre as coisas. Quanto à questão propriamente dita - "Teremos o direito de interferir na Natureza?"8 (Warnock 2007) —, Descartes nem sequer a levanta, porque o seu pensamento pressupõe uma espécie de imperativo tecnológico, que ainda comanda o devir da sociedade ocidental e, por arrastamento, ${ }^{9}$ do mundo inteiro. E como a palavra de ordem continua a ser a actualização frenética do possível, somos, mais do que nunca, profundamente modernos.

Entre o pensar que se pensa a si mesmo e o querer que se quer livre, institui-se um modelo de inteligibilidade do real que busca a máxima transparência, i.e., que exclui qualquer poder oculto. Teria de ser mecânica, por conseguinte, a natureza que lhe cabe, por o ser da máquina consistir na soma das suas partes. Para a chamada "concepção galileana do mundo", de que o cartesianismo pretende ser a metafísica, vale o princípio de que só conhecemos o que podemos construir e reconstruir. [As regras do método são a sua melhor expressão (Descartes 1987, pp.56-8).] Mas se o mecanicismo cartesiano está cientificamente datado, o mesmo não acontece com a consciência do valor da metodologia inerente à sua constituição, ou seja, a ideia de uma mathesis universalis. Trata-se do sonho de uma única ciência absoluta - justificável, segundo Descartes, porque "deve haver uma ciência geral que explique tudo o que se pode investigar acerca da ordem e da medida, sem as aplicar a uma matéria especial" (1989, p.29). (Em pleno século XX, com o Círculo de Viena, assistimos à tentativa, ainda que antimetafísica e fisicista, de realização desse sonho.) Consequentemente, a força do mecanicismo, por oposição à perspectiva hilozoísta, não está no seu alcance ontológico; radica, sim, numa atitude metodológica ímpar, e cujo sucesso, sendo incontestável, tornou irreversível esse processo que, desde Max Weber, é costume designar com o termo de "desencantamento do mundo" (2017, p.99).

\subsection{A impossibilidade de uma ciência da vida}

Apesar de tudo, Hegel não ignorava as insuficiências da filosofia cartesiana. Indo além do entusiasmo pelo responsável, à semelhança de Sócrates, ${ }^{10}$ por um novíssimo começo do filosofar, finalmente liberto do jugo teológico, o pensador alemão remeteu para a esfera do vivo a fraqueza essencial do cartesianismo. Vejamos o seu juízo global e crítico:

As determinações de Descartes são de uma espécie que é perfeitamente bastante para o mecanismo, mas não para mais; as exposições de outras mundividências (por exemplo, da Natureza vegetal e animal) são insuficientes e, portanto, desinteressantes (1995, p.85). 
Depreende-se facilmente deste excerto a inanidade de toda a Filosofia da Natureza que tenha a pretensão, como é o caso da do filósofo francês, de explicar os fenómenos orgânicos com o recurso exclusivo às determinações mecânicas, tais como: figura e movimento. Que estas são bastantes, quando se trata de um mecanismo, Hegel não o nega, pelo facto de ser explicável com base na mera disposição das partes que o constituem. Mas a realidade de um organismo não pode ser reduzida à da máquina. No que toca à transição entre o mecânico e o vivo, o mecanicismo parece incapaz de produzir uma explicação plausível. Certo é, porém, que, à distância a que estamos do Autor da Fenomenologia do Espírito, surge como algo inegável, seja como for, algum avanço científico nesta matéria. ${ }^{11} \mathrm{E}$ esse avanço, por outro lado, foi conseguido, contrariamente às expectativas hegelianas, com o recuo do vitalismo, ou seja, do modelo teleológico de inteligibilidade, contra o qual Descartes se afirmou, dando-nos, aliás, da perspectiva oposta o alvará metafísico:

Não nos deteremos [...] a examinar os fins que Deus se propôs ao criar o mundo, e por isso rejeitaremos completamente da nossa filosofia a investigação das causas finais. Porque não devemos presumir tanto de nós próprios que possamos crer que Deus nos quis fazer participar dos seus intentos. Considerando-o, porém, o autor de todas as coisas, esforçar-nos-emos tão-só por encontrar, pela faculdade de raciocinar que ele pôs em nós, como foi que aquelas que apreendemos por intermédio dos sentidos puderam ser produzidas (1978, p.78).

Este artigo, afinal, pretende ser a "certidão de óbito" do aristotelismo. ${ }^{12} \mathrm{Com}$ a rejeição das causas finais, torna-se doravante inaceitável a assimilação do cosmos a um organismo. Com efeito, a causa final responde à pergunta: Porquê ${ }^{13}$ Esta causa é de ordem intencional. Mas se a intenção é uma ilusão, até o mais acérrimo mecanicista dos nossos dias tem de admitir que "é tão poderosa que mesmo os biólogos usam o pressuposto da boa concepção como instrumento de trabalho" (Dawkins 2002, p.109). E, a este respeito, digamo-lo desde já, foi Piaget quem melhor soube apreender o âmago dessa "ilusão" e o seu produto cognitivo:

A força do vitalismo e o facto de renascer incessantemente das suas cinzas (a despeito dos desmentidos que, em cada ponto particular, lhe inflige qualquer pesquisa positiva) provêm seguramente do valor dessa intuição fundamental de uma comunidade de natureza entre a inteligência e a vida (1981, p.258).

Para o mecanicismo, tal "comunidade de natureza" não faz sentido, sendo apenas fruto de formas de pensar primitivas: sincretismo, animismo e antropomorfismo. Mas a ciência alimenta-se de uma inteligência matemática. Por conseguinte, não sendo matematizável, a noção de vida não é científica nem a realidade intencional que lhe corresponde pode ter o seu lugar no universo cartesiano (Koyré 1986, p.78). De facto, em nome de uma exigência metodológica, de clareza e distinção das ideias, Descartes 
nega a evidência empírica, não querendo ver nos seres vivos senão "relógios" de uma espécie mais sofisticada, ou seja, cujas engrenagens microscópicas estão fora do alcance da percepção. O célebre Fontenelle, ${ }^{14}$ grande divulgador dos conhecimentos científicos da sua época, não perdeu a oportunidade de ridicularizar a metáfora do relógio ${ }^{15}$ do seu mestre:

Vós dizeis que os animais são máquinas da mesma forma como o são os relógios? Mas colocai uma máquina de cão e uma máquina de cadela perto uma da outra, e disso poderá resultar uma terceira pequena máquina, enquanto dois relógios podem permanecer juntos toda a vida sem jamais produzir um terceiro relógio (cit. por Soromenho-Marques 1998, p.415).

Reflectindo, por certo, o conteúdo dos debates biológicos do seu tempo, o discurso de Fontenelle aponta para o traço essencial dos seres vivos: a capacidade de reprodução. Eis um traço rasurado, segundo Foucault, "durante toda a Idade Clássica, [porque] a vida estava sob a alçada de uma ontologia que dizia respeito por igual a todos os seres materiais sujeitos à extensão, ao peso, ao movimento; e era nesse sentido que todas as ciências da Natureza [...] tinham uma profunda vocação mecanicista" (1988, p.315). Para Descartes, em particular, essa rasura corresponde a um vazio ontológico instaurado pelo dualismo das substâncias: entre res cogitans e res extensa, não há nada. Não admira, portanto, que entre as estratégias de silenciamento da especificidade original da vida, com vista ao seu "desencantamento", se encontre em Descartes, que ignora a reprodução, a especial importância atribuída ao crescimento quantitativo dos organismos. ${ }^{16}$ Mas a fixação cartesiana nem sequer traz consigo a revelação do óbvio: o modo pelo qual os seres vivos crescem, i.e., por incorporação e transformação dos elementos formadores, contrasta fortemente com o crescimento dos minerais, que se faz por aposição - e não por intussuscepção. ${ }^{17}$ Das três características essenciais dos organismos - auto-reprodutibilidade, metabolismo e mutabilidade - (Eigen 1990, p.123), Descartes tão-somente atenta nesta última, embora o faça de uma forma pobre, ou seja, de acordo com a lógica da quantidade. É, pois, a subordinação racionalista do objecto ao método que lhe impõe a "cegueira" em relação à fenomenologia do vivo, trocando o essencial pelo acessório, e cuja diferença qualitativa, por oposição à matéria inerte, não pode ser negada.

Mas só com Cuvier, já no século XIX, ela foi, de facto, reconhecida. É com ele, diz Foucault, que "o vivo escapa, pelo menos em primeira instância, às leis gerais do ser extenso" (1988, p.315). Nas Lições de Anatomia Comparada (1805), Cuvier avança com uma tentativa de regionalização e autonomização do ser biológico, procedendo à sua definição. Para Cuvier, os organismos parecem "resistir, durante um certo tempo, às leis que governam os corpos brutos e [...] agir sobre tudo o que os rodeia, de uma maneira inteiramente contrária a estas leis" (cit. por Faure 2003, p.168). E acrescenta que devemos utilizar o conceito de vida ou força vital para designar "estas excepções, pelo menos aparentes, às leis gerais" (p.168) que governam 
a matéria. Numa linguagem moderna, diríamos que essa "resistência" ao quadro legal do mundo material - e à consequente degradação entrópica — só é possível por os corpos orgânicos agirem sobre o meio ambiente, transformando-o em função das suas necessidades, ou melhor, dele importando a "entropia negativa" indispensável à sua sobrevivência. Não significa tudo isto, contudo, que o ser vivo constitua uma excepção à legalidade físico-química e, em especial, em relação à universalidade do segundo princípio da termodinâmica, cujo âmbito de aplicação não excede os sistemas fechados. Ora, como é sabido, a organização interna do organismo só se mantém à custa da desorganização do mundo exterior. Se os tomarmos em conjunto, porém, verificar-se-á o aumento irreversível da entropia. A "excepção" é, pois, aparente. ${ }^{18}$ No entanto, com a admissão de que a existência dos seres vivos não colide com as leis da termodinâmica, não avançámos um passo em direcção à constituição da Biologia enquanto ciência da vida, porque o problema se prende então com a necessidade de saber como se explica a existência das próprias organizações. E é por isso que Cuvier, contemporâneo de Lamarck ${ }^{19}$ - e seu adversário, por ser um defensor da aposta teológica no fixismo das espécies —, ficou apenas, pese embora o elogio de Foucault, na pré-história do pensamento biológico.

\subsection{A impossibilidade de uma ciência do homem}

É na quinta e penúltima parte do Discurso do Método, que podemos ler como um resumo de uma obra póstuma - O Mundo (1664) —, que Descartes trata da diferença que separa o homem do animal, assimilando este último à natureza da máquina:

Isto [o modelo mecânico das funções vitais] não parecerá de modo algum estranho aos que, sabendo quantos autómatos diferentes, ou máquinas que se movem, a indústria dos homens pode fazer, empregando muito poucas peças em comparação com o grande número de ossos, músculos, nervos, artérias, veias e mais partes do corpo de cada animal, considerarão o corpo como uma máquina que, saída das mãos de Deus, é incomparavelmente mais bem ordenada e tem em si movimentos mais admiráveis do que qualquer das que os homens podem inventar (1987, p.95).

Em primeiro lugar, seguindo aqui uma observação de Marx (1992, p.446, n. 111), verifica-se que, diferentemente do olhar da Idade Média sobre o animal, para a qual, enquanto força de trabalho, ele representa, para o homem, uma mais-valia muito próxima, a visão cartesiana daquele, pelo contrário, dada a sua pertença ao período da manufactura, revela-se fria e distante. ${ }^{20}$ Entre autómatos e animais não há, de facto, diferença de natureza, mas apenas de grau, a qual se explica pela distância que separa a invenção humana da criação divina. E essa disparidade pode ser avaliada com base em três critérios: o número de peças e o seu tamanho; ${ }^{21}$ o nível de organização; e a complexidade dos movimentos. Em relação a todos estes itens, o 
organismo superioriza-se à máquina. Indo além dessa superioridade, a tese do automatismo dos organismos também implica a ideia de que falar de animais a propósito dos seres vivos constitui um abuso de linguagem. Tais seres não são animados, i.e., não possuem alma. Só o homem a possui, contrariando-se assim a perspectiva da física aristotélica, de acordo com a qual todo o corpo possuiria uma forma substancial. Quer isto dizer que se aplica ao homem o modelo maquinal, mas apenas enquanto o seu corpo constitui um organismo, ou seja, tendo unicamente em conta o exercício de funções independentes do controlo voluntário.

Para Descartes, além de ser uma máquina, o animal está absolutamente desprovido da capacidade de raciocínio. Vejamos como a sua argumentação sustenta a tese:

E detivera-me em particular neste assunto a fazer ver que, se algumas dessas máquinas tivessem os órgãos e a forma exterior de um macaco ou de qualquer outro animal sem razão, não teríamos nenhum meio de reconhecer que elas são de natureza diferente da dos animais; ao passo que, se as houvesse que, além da semelhança dos nossos corpos, imitassem as nossas acções tanto quanto moralmente é possível, teríamos sempre dois meios muito certos de reconhecer que, apesar disso, não eram homens verdadeiros. O primeiro é que nunca poderiam falar nem usar outros sinais, compondo-os como nós fazemos para exprimir aos outros os nossos pensamentos. [...] O segundo é que, embora fizessem várias coisas tão bem ou talvez melhor do que algum de nós, falhariam infalivelmente noutras, e descobrir-se-ia assim que não agiriam por conhecimento, mas unicamente devido à disposição dos seus órgãos. Pois enquanto a razão é um instrumento universal, que pode servir em todas as circunstâncias, esses órgãos necessitam, para cada acção particular, de alguma disposição particular; de onde resulta que é moralmente impossível que exista numa máquina a diversidade suficiente de órgãos para a fazer actuar em todas as ocorrências da vida, do mesmo modo que a nossa razão nos faz agir.

Ora, por esses dois meios pode também conhecer-se a diferença que existe entre os homens e os animais. Porque é uma coisa muito notável que não haja homens tão embrutecidos e tão estúpidos, sem exceptuar mesmo os loucos, que não sejam capazes de combinar várias palavras e de com elas compor um discurso pelo qual façam compreender os seus pensamentos; e que, pelo contrário, nenhum outro animal existe, por mais perfeito ou bem nascido que possa ser, que consiga fazer coisa semelhante. Isto não acontece porque careçam de órgãos, pois as pegas e os papagaios podem proferir palavras, mas não falar como nós, isto é, testemunhando que pensam o que dizem, ao passo que os homens que, surdos e mudos de nascença, estão privados, tanto ou mais que os animais, dos órgãos que servem aos outros para falar, costumam inventar certos sinais mediante os quais se fazem entender aos que, estando habitualmente com eles, têm vagar para aprender a sua língua. $E$ isto não prova apenas que os animais têm menos razão do que os homens, mas que não têm absolutamente nenhuma (1987, pp.95-7; grifos nossos). 
Para a compreensão do que é (o) próprio do homem, nunca será de mais realçar a fortuna histórico-cultural deste excerto de uma obra que, enquanto anúncio da Modernidade - in statu nascendi — , ilustra de maneira exemplar, ainda que obliquamente, a pulsão tecnológica de que se há-de alimentar o futuro do Ocidente.

Com a hipótese do andróide, de cuja antropomorfização plena Descartes antevê a impossibilidade moral, ${ }^{22}$ o filósofo pretende atingir um duplo objectivo: por um lado, sublinhar, de novo, a homologia das naturezas animal e maquinal; por outro, evidenciar a razão de ser da diferença entre homens e animais, dando-lhe o estatuto de alteridade ontológica radical. Donde a recusa da definição aristotélica de homem, por ser obscura e confusa. Com efeito, para o pensador francês, a ideia de animal racional viola os limites de uma correcta intuição intelectual, pois mistura domínios totalmente distintos: a extensão e o pensamento, ou seja, o material e o espiritual.

O modo pelo qual Descartes assegura a especificidade do humano assenta numa dupla estratégia argumentativa. O primeiro argumento (o mais importante, aliás) não é original. Podemos encontrá-lo na Política de Aristóteles [1998, p.55 $\left.\left(1253^{a}\right)\right]$. Designá-lo-emos, tendo em vista a sua identificação, com o termo de argumento da fala. Embora possuam voz, ou seja, sejam capazes de exprimir os seus estados internos (prazer e dor, em particular), os animais não demonstram possuir a capacidade do discurso, que lhes permitiria, como afirma Descartes, dar testemunho de que, efectivamente, pensam o que dizem. Mesmo aqueles que, dotados de órgãos fonadores e devidamente adestrados, conseguem proferir palavras, não falam, porque se limitam a repetir sons de cujo significado não têm consciência. Há entre a fala e a mera proferição toda a distância - intransponível pelo animal — que separa a "semiótica da repetição" da "semântica da criação" (Veloso 1982, p.253).

Os estudos contemporâneos, que incidem sobre a linguagem animal, tendem a mostrar que tanto Aristóteles como Descartes têm razão. Parece ser sólido o argumento da fala. Em 1978, por exemplo, dois zoólogos britânicos, Dawkins e Krebs, sustentaram a tese de que, sendo o acto de falar de natureza altruísta, seria muito estranho, do ponto de vista evolucionista, que os animais tivessem desenvolvido essa capacidade. Desde então, explorando tal linha de investigação, os biólogos chegaram à conclusão de que, na sua maioria, as trocas sinaléticas entre os animais não ultrapassam o domínio da voz, ou seja, não revelam informação sobre o mundo, mas acerca de quem envia os sinais. Muitas delas assinalam o sexo, a idade e a localização do seu emissor - e nada mais (Miller 2007, p.151).

Quanto ao segundo argumento, o da razão, abre um abismo ontológico entre o agir resultante do logos (constituindo ele, pela sua plasticidade, um órganon universal, i.e., independente das circunstâncias particulares inerentes à realização da acção) e o mero fazer programado, que se reduz a um conjunto de automatismos. Ainda que a máquina, enquanto dispositivo, possa ser mais eficaz que o homem, só pode falhar perante o imprevisto. E não é capaz de lhe dar resposta, porque depende, 
para o seu funcionamento, da articulação casuística das partes que a constituem. A força do argumento cartesiano, que invalida a possibilidade de um autómato totalmente humano, reside na distinção entre criatividade e programação. Ora, mesmo as hodiernas "máquinas de pensar", que, em relação a determinadas operações (por exemplo: o cálculo), se revelam mais eficientes do que o cérebro humano, são incapazes de criar o seu próprio programa (Changeux e Connes 1991, pp.227-31).

Os dois argumentos sustentam, contra Montaigne, ${ }^{23}$ a tese de que os animais, enquanto máquinas, não são senão seres sem razão. A polémica desracionalização do animal acarreta, pelo menos, uma dupla consequência: moralmente, o tratamento que lhe é dado pelos homens liberta-se de qualquer constrangimento, porquanto estamos perante uma criatura cujo estatuto passa a ser equivalente ao das coisas; ${ }^{24}$ além disso, também se alteram os limites do humano, visto que, por oposição à perspectiva clássica, deles se exclui a animalidade.

“Mas o que é um homem?” (Descartes 1985, p.120). — Eis a questão que ele próprio formula, mas à qual não consegue dar uma resposta cabal. ${ }^{25}$ Quando Regius, por exemplo, querendo afirmar-se como fiel discípulo do filósofo das ideias claras e distintas, concebeu o homem como um ser por acidente, foi prontamente desautorizado pelo mestre, que o denunciou como um falso epígono (1978, pp.47-8). Embora não seja, propriamente falando, uma substância, o homem, para Descartes, constitui um ser por $s i{ }^{26}$ Porém, se ele, contrariando a perspectiva aristotélica, afirma que a alma e o corpo são substâncias completas e independentes, será possível concebê-las como partes substanciais de um mesmo ser? Em relação a este problema, acumulam-se as dificuldades teóricas (em especial, de 1643 em diante, aquando da sua correspondência com a Princesa Isabel). São tantas que ele, paradoxalmente, se vê forçado a assumir, por fim, que só quem cessa de filosofar é capaz de compreender a união substancial da alma e do corpo. ${ }^{27}$ Admite, por consequência, que a realidade do ser humano não pode ser objecto de conhecimento. Quer isto dizer, em suma, que não há nem pode haver uma ciência cartesiana do homem.

\section{A revolução darwiniana e a falência do humanismo teórico}

Para salvaguardar a dignidade do homem, que assentava na posse de uma alma independente da matéria, Descartes envolveu-se numa série de embaraços insolúveis. Em resumo: de um lado, a necessidade mecanicista; do outro, a liberdade do espírito. Como conciliá-las? Como explicar a interacção pela qual alma e corpo se tornam entidades comunicantes? Este problema veio a ser a verdadeira cruz dos cartesianos. Mas o dualismo das substâncias acarretou, acima de tudo, a ininteligibilidade da experiência concreta do ser humano. É antropologicamente que se faz sentir o peso da 
negação da singularidade do impulso vital. Separando, contra Aristóteles, o animal do racional, e reduzindo aquele à máquina, Descartes concebeu o homem como um ser à parte, i.e., sem qualquer relação com a Natureza. Se o mecanicismo cartesiano, seguindo a lição de Galileu, procede à reunião dos dois mundos da física aristotélica (o celeste e o terrestre), com a sua consequente transformação num autêntico universo, regido pelas mesmas leis do movimento, esse esforço de unificação intelectual brota de um sujeito que, enquanto fonte de certeza, não tem na Natureza senão o seu negativo. Em Descartes, a desnaturalização do homem e a desantropomorfização da Natureza são processos concomitantes.

Em que sentido, de facto, podemos nós atribuir a Descartes um humanismo teórico? Não é só por nele existir a preocupação de subtrair o ser do homem ao império da regularidade mecânica que domina o comportamento dos corpos, mas também porque se afirma a realidade do mundo como o conjunto das representações cujo centro é o sujeito, na sua qualidade de agente cognitivo capaz de as validar. Quer isto igualmente dizer que o mundo se constitui como um artefacto da inteligência matemática, tanto mais que, em conformidade como o mecanicismo, se perdeu de vista a distinção aristotélica entre natureza e arte.

Descartes uniu o que o Estagirita tinha separado - e separou o que este último tinha unido. Ora, à luz da revolução darwiniana, a falência do humanismo teórico ganha aqui um duplo alcance: em primeiro lugar, naturaliza-se o homem, dele fazendo o resultado de uma longa evolução biológica; em segundo, mostra-se que a Natureza não constitui apenas o reino da legalidade mecânica, indiferente à seta do tempo, mas tem uma História.

\subsection{Entre homem e animal: a rasura da diferença antropológica}

Pese embora o engenho do discurso foucauldiano sobre os grandes campos epistemológicos, cabe a Darwin, e não a Cuvier, o título de "Galileu da Biosfera". "Foi ele quem trouxe finalmente a Biologia para a moderna visão mecanicista do mundo" (Lewontin 1998, p.118). À semelhança do Pisano, cuja dinâmica uniu os domínios da Terra e do Céu, também o naturalista inglês, com a sua teoria da evolução, reuniu, sob o mesmo paradigma legal — o mecanismo da selecção natural —, os reinos do Homem e da Vida. Além de permitir a unificação de uma série de áreas disciplinares díspares da Biologia [Paleontolgia, Embriologia, Morfologia, etc. (Ruse 2002, p.80)], esse mecanismo é capaz de explicar a sobrevivência do ser vivo (significando, para ele, um bem em si mesmo) sem recorrer à apreensão deste último, i.e., à atracção de um estado final vantajoso para o organismo, como causa desse processo. Como Darwin invocou apenas, de forma explícita, as condições iniciais que o originaram [em suma: "struggle for life" (1996, p.52)], tornou respeitável a explicação que Descartes tinha banido da ciência, i.e., a teleológica, que leva agora o nome de teleonomia. ${ }^{28} \mathrm{Como}$ ? 
Fornecendo, de acordo com o que ficou dito, um esquema geral para a sua transposição em termos mecânicos.

Para Darwin, a diferença antropológica, tal como Descartes a pensou, era um obstáculo epistemológico. Ainda que num contexto muito específico, o da expressão das emoções, o naturalista inglês soube exprimir a ideia com inegável vigor: "No doubt as long as man and all other animals are viewed as independent creations, an effectual stop is put to our natural desire to investigate as far as possible the causes of Expression" (1965, p.12). Todavia, o projecto de completa animalização do homem, no quadro do evolucionismo, depara-se, pelo menos, com uma dificuldade teórica: a origem da linguagem (Crow 2008, p.56). Não se compreende em que medida a luta pela vida, através da conservação e ampliação das variações específicas - que são vantajosas para os indivíduos - , teria favorecido a emergência da fala. Aparentemente, atendendo à sua natureza altruísta, uma eventual variação nesse sentido não poderia senão ter sido eliminada pela selecção natural. Vejamos porquê: por um lado, se é fácil entender como esse mecanismo pode explicar o aparecimento de uma determinada característica física (como é o caso de um certo comprimento do pescoço), isso deve-se ao facto de podermos não só descrever um único indivíduo com a dita propriedade (por exemplo: uma girafa cujo pescoço apresenta um comprimento superior ao normal), mas também ver a vantagem comparativa (em relação aos outros indivíduos da mesma espécie) inerente à sua posse (neste caso, a possibilidade de alcançar as folhas das árvores mais altas); por outro, se quisermos aplicar este esquema explicativo à aquisição da linguagem, tornar-se-à clara a implausibilidade da hipótese naturalista, porque não é possível, realmente, descrever um falante sem pressupor, desde logo, uma comunidade de falantes. Pelo facto de ser uma actividade colectiva, parece absurda a ideia de que a linguagem humana se desenvolveu à custa das vantagens competitivas dos seus utentes, por comparação com aqueles que dela não faziam uso.

\subsection{Entre ciência e filosofia: o discurso edificante do evolucionismo}

Relativamente ao darwinismo, urge pôr o problema do seu valor epistémico. Perfila-se então a pergunta: Será que o evolucionismo é uma teoria explicativa ou uma narrativa edificante? (Brun 1991, p.67). Mas não está aqui em questão o facto da evolução, do qual nenhum biólogo contemporâneo duvida. Trata-se, antes, de discutir o enquadramento teórico desse mesmo facto, ou melhor, as suas condições de possibilidade. Ora, fazendo jus à honestidade intelectual do Autor d'A Origem das Espécies ${ }^{29}$ (1859), tudo indica que o seu discurso sobre a evolução não teria sido possível sem o conhecimento do "princípio da população" de Malthus (Ruse 2002, p.71). 30 "De facto, toda a teoria de Darwin conduz a uma analogia imprudente entre a evolução por selecção natural e a teoria económica política do capitalismo precoce, tal como 
foi desenvolvida pelos economistas escoceses"31 (Lewontin 1998, p.30). Da realidade desta influência malthusiana, todavia, não podemos inferir (como é habitual entre os relativistas culturais) que a evolução acaba por ser redutível a uma construção social. Tal conclusão é inaceitável. Encontra-se alhures, por consequência, o essencial da avaliação do darwinismo.

Dadas as lacunas do registo dos fósseis e a natureza aleatória inerente à sua recolha, é insuficiente, relativamente à reconstrução da árvore genealógica da Humanidade, o poder explicativo da indução em que assenta a perspectiva evolucionista. Sabendo isso, Darwin, de uma forma sub-reptícia, almeja deduzir o homem do antropomorfo. Torna-se, assim, uma vítima voluntária da ilusão resultante de um olhar retrospectivo: o homem nunca teria sido o que é, diz-nos o defensor do evolucionismo, se antes dele, mas indo na sua direcção, não tivesse acontecido o que aconteceu, ou seja, o processo de hominização. Eis-nos, como é evidente, perante uma petição de princípio. "Num tal procedimento, o homem desempenha um papel de um arquétipo que opera com efeito retroactivo, uma vez que falar de antropóide é, desde logo, falar do homem [... ]" (Brun 1991, p.70). Com esta dificuldade em mente, é possível colocar nos seus devidos limites o estatuto epistemológico da teoria da evolução:

A articulação entre a teoria da selecção e o sistema de classificação genealógica difere, por conseguinte, da articulação entre a física teórica e a física experimental, uma vez que o processo concreto da descendência não pode ser conceptualizado em termos dedutivos: a história é refractária à dedutibilidade (Nowinski 1981, pp.236-7; grifo nosso).

Todos os seres vivos são produtos históricos. Aqui reside, na sua essência, o problema fundamental da Biologia. O próprio Dawkins, o mais famoso admirador contemporâneo de Darwin, não deixa de o reconhecer: "Ao contrário dos inventores humanos, a selecção natural não pode descer a colina [... ]" (2002, p.91). (Esta metáfora fala por si, porque é deveras reveladora da ideia de evolução que o Autor tem em mente, assimilando-a implicitamente à noção de progresso, o que é muito discutível. ${ }^{32}$ ) Pelo facto de o processo se caracterizar pela irreversibilidade, não está ao nosso alcance, efectivamente, a sua demonstração experimental. Falando cruamente, podemos dizer que nunca se viu uma espécie a engendrar outra nem sequer assistimos às suas transformações sucessivas. É por isso que o mesmo pensador, a páginas tantas do livro que temos vindo a citar, afirma reveladoramente: "Uma característica essencial da evolução é ser gradual" (Dawkins 2002, p.95). Dada a impossibilidade empírica de a acompanharmos ao longo do tempo paleontológico, admite que é uma "questão de princípio". Ora tal admissão de impotência permite o género de crítica à doutrina que é frequente entre os filósofos: "A teoria [evolucionista] substitui-se aos factos, interpolando-se, e reconstitui a epopeia anátomo-fisiológica, como se tratasse de reconstituir uma saga ou uma cantilena" (Brun 1991, p.68). O célebre professor de 
Oxford defender-se-ia desta censura, ou melhor, tentaria evitá-la, descendo de nível de análise, ou seja, apelando para conhecimentos inacessíveis à época de Darwin:

Existem centenas de proteínas diferentes, cada uma mudando em cada milhão de anos segundo o seu rimo característico, servindo cada uma para reconstruir independentemente as árvores genealógicas. Todas elas contribuem muito para a mesma árvore genealógica - a qual, a propósito, constitui mais do que uma boa prova, se acaso houvesse necessidade de provas, da verdade da teoria da evolução (Dawkins 2002, p.57; grifo nosso).

É a mudança de perspectiva - a passagem da anatomia para a genética - que permite um outro enquadramento da teoria da evolução das espécies, dando-lhe, como diz Allègre, e descontando o exagero da linguagem, "um elemento de prova absoluta" (2005, p.283). Seja como for, o neodarwinismo, conjugando a necessidade da selecção natural com o acaso da mutação genética, não resolve o problema da evolução, o qual, na sua essência, pode ter a seguinte formulação:

[... ] será possível atribuir o carácter definido das curvas de evolução a uma acumulação aleatória de microfenómenos (conhecidos, ou desconhecidos), ou será que o traçado dessas curvas exige uma inteligibilidade duma ordem diferente (cuja forma própria haveríamos então de procurar)? (Meyer 1981, p.185)

À escala antropológica, eis-nos perante a questão de saber se a variabilidade aleatória do genoma será suficiente para construir um modelo razoável da evolução genética anterior ao aparecimento do homem. No atinente aos modelos susceptíveis de ser propostos no quadro da evolução, será sempre difícil a sua validação (Changeux e Ricœur 2001, pp.183-5), porque hão-de tomar como objecto acontecimentos pretéritos, i.e., enquanto tais, irrepetíveis.

\section{A digitalização do vivo e a morte do vitalismo}

Para Dawkins, o vitalismo teve a sua morte definitiva em 1953: "Mesmo os filósofos que tenderam para uma visão mecanicista da vida [e entre os quais sobressai o nome de Descartes] não se atreveram a esperar por uma tão completa realização dos seus sonhos mais temerários" (2002, p.31). Já não é o relógio, contudo, que serve de modelo para a explicação integral do organismo, mas o computador. A alteração não se deveu tão-somente à própria evolução tecnológica, mas implicou também uma mudança de nível analítico, com o olhar do biólogo a contemplar finalmente (indo além da visão macroscópica) a referência microfísica. Com a descoberta da estrutura molecular dos genes, unidades básicas da hereditariedade, assistimos, ainda segundo Dawkins, a uma autêntica modelação digital dos fenómenos vitais. Efectivamente, o 
mecanismo que regula as combinações génicas pode ser assimilado a um programa informático. ${ }^{33}$ Existe, no entanto, uma dissemelhança, pois estamos perante um código quaternário - e não binário. Os símbolos são as quatro bases nitrogenadas da molécula que contém os genes: A (adenina), T (timina), G (guanina) e C (citosina). Em conformidade com a regra segundo a qual A se combina com $\mathrm{T}$ e $\mathrm{G}$, por sua vez, com C, formam-se duas longas cadeias emparelhadas, originando-se a estrutura química dos sistemas vivos: a dupla espiral de ácido desoxirribonucleico. A informação nela contida converte-se em proteínas, ${ }^{34}$ as quais são compostas por renques de aminoácidos, cujo número ascende a vinte. Havendo, todavia, apenas quatro nucleótidos, como é possível tal conversão? Se os agrupamentos simbólicos tivessem duas letras, seriam insuficientes $\left(4^{2}=16\right)$; se tiverem três, porém, serão já bastantes: $4^{3}=64$ (Allègre 2005, p.302). Eis, pois, a sequência em que está codificada a mensagem susceptível de determinar a natureza dos ácidos aminados. Consequentemente, a linguagem dos genes resulta de um alfabeto de quatro sinais, que se combinam entre si de maneira que formem, por assim dizer, palavras de três letras. Delimitá-las, no entanto, não se tem revelado uma tarefa simples. Não tendo os genes limites "claros e distintos", 35 havemos de concluir que, ao longo de uma repetitiva série de letras, poderá aparecer, por fim, uma ou outra mensagem significativa (Bertranpetit e Calafell 2008, pp.23-4). Não espanta, pois, que entre os geneticistas se diga habitualmente que grande parte do genoma humano não é senão "lixo". ${ }^{36}$

Mas será que a descoberta do código genético significa, como julgavam Crick e Watson, a resolução do "enigma da vida"? A não ser que queiramos confundir a explicação funcional do mecanismo dos fenómenos vitais com a determinação da sua origem, só pode ser negativa a resposta. Se a química sabe muito da vida, para já, pelo menos, não sabe tudo. Mesmo admitindo que seja da sua competência a análise do fenómeno original, i.e., que gerou a possibilidade da auto-replicação orgânica, certo é que, como até reconhece um "fundamentalista do ADN" (Dawkins 2002, p.159), não há provas de que, aquando da emergência do processo de hereditariedade, o código primitivo tivesse a estrutura do actual abecedário genético.

\subsection{Aporias do reducionismo mecanicista}

Richard Dawkins não está só, quando nos dá a notícia de um fim irreversível da filosofia vitalista. Jean-Pierre Changeux não lhe fica atrás. Em diálogo com Paul Ricœur, afirma que o objectivo da Biologia Molecular continua a ser o que sempre foi: a compreensão físico-química da vida da célula (Changeux e Ricœur 2001, p.12). Eis, sem dúvida, e assumidamente, um programa de investigação reducionista. Atendendo aos resultados práticos que dele continuamente derivam, e dos quais se fazem até parangonas ultramediáticas, a sua força não pode ser desmentida, residindo ela, portanto, na fecundidade de um efectivo método de pesquisa experimental (Piaget 1981, 
p.259). Mas se é possível, de facto, atingir uma explicação estritamente mecanicista da organização e do comportamento dos seres vivos, com a consequente redução do todo à soma das suas partes, isso pressupõe também, para uma efectiva validação desse programa reducionista, a possibilidade de uma reconstituição do caminho inverso. A actualização de tal possibilidade implicaria, por si só, a verdade de uma ontologia monista de cariz materialista.

Estamos ainda longe da solução do problema da "vida artificial", cuja realização teria de implicar não só uma síntese molecular apropriada de ADN, mas também um arranjo ambiental propício à produção de um ser vivo à conta dessa macromolécula sintética. Enquanto isto não for uma realidade, teremos de continuar a colocar a questão "Que é a vida?", ainda que muitos cientistas, por força de um positivismo atávico, se recusem a considerá-la uma boa pergunta (Eigen 1990, p.122). Nem todos, no entanto, são da mesma opinião. Assistimos, de resto, neste início do século XXI, a um regresso singular desse "mistério de todos os mistérios". Para esse retorno, Michel Morange apresenta várias razões, das quais nos apraz salientar a desilusão proveniente das respostas da Biologia Molecular:

Si l'énigme de la vie trouve son origine dans l'existence d'une information génétique, comment se fait-il que le décryptage complet de cette information nous en apprenne si peu sur les êtres vivants? Où se cache ce mystérieux programme génétique dont les premiers biologistes moléculaires avaient supposé qu'il contrôlait entièrement la vie et le développement des organismes? La lecture du grand livre de la vie n'en a pas révélé la trace (2004, pp.286-7).

Os "fundamentalistas do ADN", que nesta molécula gigante vêem o "Livro da Vida", esqueceram-se de que ela, para se reproduzir e multiplicar, necessita do organismo em que está inscrita. ${ }^{37}$ Com efeito, sem estrutura celular, metabolismo e energia, o ADN não se reproduz nem pode desempenhar nenhuma função. Explicar a "Função de Utilidade de Deus", como o faz Dawkins (2002, pp.105-42), apelando para a maximização da sobrevivência dos genes significa, para todos os efeitos, a troca das galinhas pelos ovos (Rose 2007, p.361). Ora, se quisermos dar sentido à pergunta acerca da origem da vida, a nossa opção será outra, dando então prioridade à organização - e não às suas partes. Só que, ao contrário do que pretende o reducionista, defender a ideia de que a vida se constitui como um acontecimento holista não significa aderir às teses vitalistas. Ninguém pode contestar o facto de um organismo ser exclusivamente constituído por átomos. Mas estamos perante entidades inanimadas. A razão de ser da animação do todo não pode então estar nas propriedades das partes que o constituem nem sequer na sua soma mecânica, porquanto a vida não consiste num fenómeno cumulativo. Portanto, o princípio susceptível de a explicar tem de se situar num patamar superior àquele em que se move a Biologia Molecular. 


\subsection{Biologia molecular: da euforia ideológica à depressão epistemológica}

Em 1990, quando o Departamento de Energia dos Estados Unidos da América patrocinou o projecto bilionário de sequenciação integral do genoma humano, eram muitas as promessas de uma produção industrial de fármacos personalizados — "feitos à medida do doente" —, que inaugurariam a era da terapia génica: a substituição de um gene deficiente por um exemplar em bom estado, da qual resultaria, em última instância, a eliminação do presente intervalo entre cirurgia e bioquímica (Sulston 2007, pp.257-9). Por ser cada vez menor a descoberta, pela via da síntese química, ${ }^{38}$ de medicamentos inovadores, do ponto de vista do tratamento das mais graves doenças, tornou-se sinal de esperança a busca biotecnológica de alternativas terapêuticas. No entanto, a decifração, no ano de dois mil, do mapa genético do ser humano, não trouxe os benefícios que então fizeram as manchetes da imprensa mundial (Krawczak 2008, p.105).

Com a perspicácia dos espíritos fortes, Lewontin antecipara já, em 1991, o fracasso dessas promessas (1998, pp.74-82), relegando-as para o domínio da manipulação da opinião pública, pois o desenvolvimento biológico não é determinista, mas probabilístico: "Mesmo que conhecêssemos a completa especificidade molecular de todos os genes de um organismo não poderíamos prever o que esse organismo viria a ser" (1998, p.50). A não ser que tenhamos por modelo do vivo o funcionamento patológico dos organismos, seremos obrigados a partilhar esta visão da vida. A própria evolução da Biologia Molecular complexificou o cenário epistemológico da disciplina, porque acabou por destruir o seu "dogma central”: a correspondência biunívoca entre um gene e uma enzima. Afinal, cada gene especifica a constituição molecular de diferentes proteínas. O facto de o descobrirmos, por conseguinte, não implica que saibamos o que fazem os seus produtos. Além disso, o mesmo gene influencia a natureza de várias características fenotípicas, e cada uma delas, por sua vez, pode depender de vários genes. $\mathrm{E}$ devemos, por último, ter bem presente a variedade genética do ser humano. Com efeito, um único gene idêntico apresenta diversas sequências (e ainda, por vezes, número de cópias) em diferentes indivíduos. ${ }^{39}$

Embora se tenha revelado falsa a visão da genética clássica, segundo a qual, além de não sermos mais do que um agregado de genes independentes, cada um deles seria responsável pela determinação unívoca de uma única propriedade fenotípica, Dawkins, ilustrando em todo o seu esplendor a perspectiva reducionista, não se coibiu, por exemplo, a propósito da homossexualidade, de aventar a hipótese de uma predisposição de raiz genética (2002, p.40). Estaria à procura do "gene gay" (Hamer e Copeland 1998, pp.175-81)? ${ }^{40}$ Admitindo, contudo, a sua existência, não teríamos igualmente de admitir tantos genes quantos os tipos de orientação sexual? Com o presente exercício de reductio ad absurdum, havemos de concluir que, além de ser 
um programa metodológico, segundo o qual a verdade do todo está nas partes que o constituem, o reducionismo é também um compromisso ideológico, de acordo com o qual "estamos totalmente à mercê de forças internas presentes dentro de nós desde o nascimento" (Lewontin 1998, p.117). Para este geneticista, a Biologia Molecular ilustra exemplarmente essa dupla faceta, sendo um lugar privilegiado para avaliar as relações entre ciência e política. ${ }^{41}$

Toda a euforia ideológica que se criou em torno da descodificação do genoma humano - e dos interesses comerciais subjacentes a essa descoberta ${ }^{42}$ - esconde a "depressão epistemológica" (Meyer 1981, p.157) em que vive a Biologia. Muito antes de se avançar com tal projecto, já Meyer denunciava a "obsessão bioquímica" (1981, p.161) como um obstáculo ao advento de uma teoria biológica, no sentido integral do termo. Uns anos largos depois, Thom repisou o tom, criticando a Biologia Molecular por ter por fundamento "a ideia de que, para cada processo, se pode encontrar um agente químico responsável" (1985, p.64). Foi mais longe ainda, na sua crítica, afirmando que o progresso da disciplina se tornou um pseudoprogresso, porque não ultrapassou o domínio cognitivo da mera descrição (1985, p.65), cuja necessidade, no entanto, não podemos ignorar (Bertranpetit e Calafell 2008, p.48). Quanto ao domínio prático, até aí, segundo Thom, a realidade dista da propaganda, porquanto o aumento dos conhecimentos biológicos "não teve efeitos radicais sobre o melhoramento da saúde e da longevidade" (1985, p.62). Tendo em conta o facto de esta declaração ter sido produzida em 1980, é caso para dizer que a mesma, devidamente actualizada, só poderia sair reforçada, do ponto de vista clínico. ${ }^{43}$ Basta atentar, por exemplo, em relação às bandeiras da ciência, no combate ao cancro. Sendo essa batalha uma delas, e talvez a mais mediática, é bem o sintoma de uma certa irresponsabilidade dos cientistas que, em nome do urgente financiamento dos seus programas de investigação, acabam por empenhar a sua palavra em perspectivas "milagrosas" de curto prazo. Efectivamente, é notório o contraste entre os avanços no domínio da descodificação dos mecanismos moleculares que estão na base dessa doença e a incapacidade relativa à tradução terapêutica e eficaz desses novos conhecimentos. ${ }^{44}$

\section{Os limites do humano e a responsabilidade do cientista}

"Nós - e isto significa todos os seres vivos - somos máquinas sobreviventes programadas para difundir a base de dados digital que fez a programação" (Dawkins 2002, p.33). Indo além da questão do valor de verdade desta proposição, ${ }^{45}$ devemos interrogar-nos sobre a imagem do homem que dela resulta. Por um lado, somos confrontados com a sua naturalização extrema, porquanto a ciência certifica a ideia de que o património genético de todos os seres vivos, sem excepção, possui como matriz um único código: a dupla hélice de Crick e Watson; por outro, desvelando 
agora a faceta anti-humanista da metáfora de Dawkins, acentua-se a mecanização do modelo que almeja compreender os limites do humano, e cuja figura adquire o estatuto de veículo robótico unifuncional, ou seja, exclusivamente destinado à função de garantir a perpetuação dos genes da humanidade. Também podemos limitar o alcance desta tese, a do "gene egoísta" (Dawkins 2018), mostrando que se trata, em última instância, de uma versão sofisticada de um velho estribilho: o preço a pagar pela reprodução da espécie consiste na morte do indivíduo. O que há de novo, no entanto, deriva da concepção deste último, enquanto fenótipo, como mera projecção do genótipo. Caímos, assim, num essencialismo genético susceptível de legitimar o determinismo biológico. É esta doutrina, na sua qualidade de "ideologia científica moderna" (Lewontin 1998, p.37) que sustenta a confusão conceptual entre hereditariedade e fixidez (1998, pp.59-64), servindo até de caução para as desigualdades sociais. ${ }^{46}$ É verdade que Dawkins, respondendo a Lewontin, defende-se da sua acusação com o argumento de que só nós, seres humanos, "temos o poder de desafiar os genes egoístas que herdámos" (2018, p.281). Ora, como exemplo dessa "rebelião" (2018, p.456), assinala precisamente o uso quotidiano dos métodos anticonceptivos. Mas trata-se de um argumento que parece ressuscitar o dualismo cartesiano. Vejamos porquê:

Só quando estamos sob a influência da ideia de um fantasma na máquina é que podemos contrapor aquilo que a "natureza" me obrigaria a fazer àquilo que eu, o verdadeiro eu, faço. E isto é um equívoco, pois o eu verdadeiro, biológico, não é uma criatura que se revolta contra a tirana do seu cérebro (Blackburn 2018, pp.26-7; grifo nosso).

Assim sendo, descrever a contracepção como um mecanismo pelo qual se manifesta a liberdade do agente relativamente à herança genética surge como algo inconsistente, até, sob a perspectiva da obra do próprio Dawkins. A inconsistência torna-se gritante, por fim, quando o Autor apela antifenomenologicamente para uma suposta insularização do desenvolvimento cerebral: "Nós, isto é, os nossos cérebros, somos suficientemente independentes e estamos suficientemente separados dos nossos genes para podermos rebelar-nos contra eles" (Dawkins 2018, p.456). Além de ser muito questionável, de um ponto de vista fenomenológico, a redução da humanidade do homem ao conteúdo da sua caixa craniana, não se compreende como pode estar separado dos genes o que, de facto, à luz do evolucionismo neodarwiniano que Dawkins propugna, deles depende, tanto genética como estruturalmente.

Por tudo o que acima dissemos, adquire a figura do incontornável o problema da responsabilidade social do cientista e do controlo democrático do desenvolvimento científico, ${ }^{47}$ tanto mais que a ciência, pela sua natureza, "só pode progredir" ${ }^{48}$ (Galilei 1987, p.49). E se assim é, como diz Thom, o verdadeiro problema consiste em avaliar a qualidade desse mesmo progresso $(1985$, p.61) - e, em particular, no domínio 
epistémico que aqui nos interessa. Para o efeito, e tendo em conta o escopo deste excurso sobre a ideia de vida, importa sublinhar, reter e registar o seguinte "alerta amarelo":

Inúmeras ciências, ou uma combinação delas, podem trazer progressos nos modos como nos entendemos. Temos de ser cautelosos, porém, relativamente à confusão entre a ciência e a ideologia de cientistas específicos. Isto é particularmente verdadeiro acerca do intenso namoro que a Biologia tem tido com a impossibilidade do altruísmo (Blackburn 2018, pp.25-6; grifo nosso).

\section{Coda mínima}

Será que superámos, na realidade, os obstáculos epistemológicos constitutivos da herança cartesiana? Do alto de quatro séculos de ciência, haverá quem responda afirmativamente. Mas os impasses da genética molecular e do evolucionismo - teorias nucleares da Biologia ${ }^{49}$-, e de que demos conta atrás, deveriam obrigar-nos à indispensável humildade intelectual. Como se mantém aberta a pergunta pela origem da vida e, portanto, do próprio homem, parece que (pese embora a descodificação das bases moleculares dos mecanismos vitais ${ }^{50}$ ) não conseguimos ir muito além do truísmo que nos diz que o ser vivo representa um estádio superior de organização da matéria.

Quanto à questão que está na base deste excurso, só lhe podemos responder de forma matizada. Metodológica e eticamente, somos, mais do que nunca, cartesianos. Tanto o programa reducionista como a vontade de poder - que aquele, pela passagem da magia à tecnologia, ${ }^{51}$ permite tornar efectiva - são princípios propulsores do trabalho científico, que assim se põe, enquanto força de produção, ao serviço da transformação material do mundo. Queremos continuar a ser o senhor do ente (ou doente ${ }^{52}$ ), dando irreversivelmente corpo ao sonho cartesiano. Nada nos diz, por enquanto, pese embora a devastação da Terra, a proposição do "pastor do ser" por Heidegger (1985, p.55), cuja figura conceptual parece não transcender os limites da metáfora poética.

Sob uma perspectiva epistemológica, porém, talvez nos falte a consciência metafísica das dificuldades inerentes à constituição de um discurso que articule logicamente o modelo do vivo com a experiência do vivido (Changeux e Ricœur 2001, p.74). Na esteira deste último, podemos dar-lhe o nome de "discurso misto" sobre a "terceira substância". ${ }^{53}$ (Bem o tentou articular, Descartes, mas sem sucesso.) Quais são as suas condições de possibilidade? Trata-se de um problema estrutural do nosso tempo vivido (Changeux e Ricœur 2001, p.46), mas cuja solução não se compadece com a pressa acrítica com que tanto cientistas como filósofos pretendem atingi-la. ${ }^{54}$ É por isso que continuamos a ter más respostas, sejam elas dualistas ou monistas. 


\section{Referências}

Allègre, C. 2005. Um Pouco de Ciência para Todos. Trad. de J. Branco. Lisboa: Gradiva.

Aristóteles. 1998. Política. Ed. bilingue. Trad. de A. C. Amaral e C. C. Gomes. Lisboa: Vega.

Bertranpetit, J.; Calafell, F. 2008. Entender a Diversidade Humana. Trad. de J. G. Flores. In:

R. M. Cardoso (org.) Biologia: Crítica do Contemporâneo (Conferências Internacionais de Serralves), pp.19-48. Porto: Fundação Serralves.

Blackburn, S. 2018. As Grandes Questões da Filosofia. Trad. de D. M. Soares e D. Murcho. Lisboa: Gradiva.

Brun, J. 1991. A Mão e o Espírito. Trad. de M. R. A. Matos. Lisboa: Edições 70.

Changeux, J.-P; Connes, A. 1991. Matéria Pensante. Trad. de C. Lourenço e A. P. Oliveira. Lisboa: Gradiva.

Changeux, J.-P.; Ricœur, P. 2001. O que nos faz pensar? Trad. de I. Saint-Aubyn. Lisboa: Edições 70.

Crow, T. 2008. As Origens Genéticas do Moderno Homo Sapiens. Trad. de F. Villas-Boas. In: R. M. Cardoso (org.) Biologia: Crítica do Contemporâneo (Conferências Internacionais de Serralves), pp.49-68. Porto: Fundação Serralves.

Darwin, C. 1996[1859]. On The Origin of Species by Means of Natural Selection, or The Preservation of Favoured Races in The Struggle for Life. Oxford: Oxford University Press.

Darwin, C. 1965[1872]. The Expression of the Emotions in Man and Animals. Chicago and London: The University of Chicago Press.

Dawkins, R. 2002. O Rio que Saía do Éden: Uma Perspectiva Darwiniana sobre a Vida. Trad. de M. T. Castanheira. Lisboa: Rocco - Temas e Debates.

Dawkins, R. 2018. O Gene Egoísta: Edição Comemorativa do $40^{\circ}$ Aniversário. $5^{a}$ edição. Trad. de A. P. Oliveira, M. Abreu e M. F. Carmo. Lisboa: Gradiva.

Descartes, R. 1987[1637]. Discurso do Método. Trad. de J. Gama. Lisboa: Edições 70.

Descartes, R. 1985[1641]. Meditações sobre a Filosofia Primeira. Trad. de G. Fraga. Coimbra: Livraria Almedina.

Descartes, R. 1978[1644]. Princípios da Filosofia. $3^{a}$ edição. Trad. de A. Ferreira. Lisboa: Guimarães \& $\mathrm{C}^{a}$ Editores.

Descartes, R. 1989[1701]. Regras para a Direcção do Espírito. Trad. de J. Gama. Lisboa: Edições 70.

Eigen, M. 1990. Estádios para a Vida. Trad. (rev. científica) de J. M. Gago e O. Ferreira. In: F. Gil (org.) Balanço do Século: Ciclo de Conferências Promovido pelo Presidente da República, pp.121-45. Lisboa: Imprensa Nacional-Casa da Moeda.

Faure, M.-R. 2003. Conhecimento do Ser Vivo. In: AA. VV. As Grandes Noções da Filosofia, pp.135-62. Trad. de A. Rabaça. Lisboa: Instituto Piaget.

Ferreira, M. J. C. 1998. A Leitura Hegeliana de Descartes. In: L. R. Santos et al. (orgs.) Descartes, Leibniz e a Modernidade, pp.437-47. Lisboa: Edições Colibri.

Foucault, M. 1988. As Palavras e as Coisas. Trad. de I. Braga. Lisboa: Edições 70.

Galilei, G. 1987[1632]. Diálogo dos Grandes Sistemas: Primeira Jornada. $2^{a}$ edição. Trad. de M. Brito. Lisboa: Gradiva.

Hamer, D.; Copeland, P. 1998. Aprenda a Viver com os seus Genes. Trad. de J. S. Tavares. Lisboa: Livros do Brasil. 
Hegel, F. 1995[1833-1836]. Introdução às Lições sobre História da Filosofia. Trad. de J. BarataMoura. Porto: Porto Editora.

Heidegger, M. 1985. Carta sobre o Humanismo. $3^{a}$ edição. Trad. de E. Stein. Lisboa: Guimarães Editores.

Hobbes, T. 1988[1651]. Leviatã ou Matéria, Forma e Poder de um Estado Eclesiástico e Civil. $4^{a}$ edição, vol 1. Trad. de J. P. Monteiro e M. B. N. Silva. São Paulo: Nova Cultural.

Keller, E. F. 2004. Génome, Postgénome: Quel Avenir pour la Biologie? La Recherche 376: 36-7.

Koyré, A. 1986. Considerações sobre Descartes. $3^{a}$ edição. Trad. de H. Godinho. Lisboa: Editorial Presença.

Krawczak, M. 2008. A Diversidade Genética Humana: uma Perspectiva Médica. Trad. de J. G. Flores. In: R. M. Cardoso (org.) Biologia: Crítica do Contemporâneo (Conferências Internacionais de Serralves), pp.91-107. Porto: Fundação Serralves.

Le Guyader, H. 1984. A Filotaxia ou o Sonho do Cristal Vivo. Trad. de A. M. Carneiro (com a colaboração de M. Banet). Análise 1(2): 79-118.

Marx, K. 1992[1867]. O Capital. Livro I, Tomo II. Trad. de J. Barata-Moura et al. Lisboa: Editorial "Avante!".

Papert, S. 1981. Epistemologia da Cibernética. Trad. de F. Sardo e S. Dias. In: J. Piaget (org.) Lógica e Conhecimento Científico, vol. 2, pp.191-207. Porto: Livraria Civilização.

Miller, G. 2007. Como Evoluiu a Linguagem? Trad. de M. J. Figueiredo. In: H. Swain (org.) Grandes Questões Científicas, pp.149-56. Lisboa: Gradiva.

Montaigne, M. 1991[1580]. Ensaios. Trad. de S. Milliet. São Paulo: Nova Cultural.

Morange, M. 2004. L'Énigme de la Vie. Revue Philosophique 3: 286-7.

Morange, M. 2005. Les Secrets du Vivant: Contre la Pensée Unique en Biologie. Paris: La Découverte.

Lewontin, R. 1998. Biologia como Ideologia: a Doutrina do ADN. Trad. de M. Amaral. Lisboa: Relógio d'Água.

Meyer, F. 1981. Situação Epistemológica da Biologia. Trad. de F. Sardo e S. Dias. In: J. Piaget (org.) Lógica e Conhecimento Científico, vol. 2, pp.157-90. Porto: Livraria Civilização.

Nowinski, C. 1981. Biologia, Teorias do Desenvolvimento e Dialéctica. Trad. de F. Sardo e S. Dias. In: J. Piaget (org.) Lógica e Conhecimento Científico, vol. 2, pp.228-54. Porto: Livraria Civilização.

Piaget, J. 1981. Os Dois Problemas Principais da Epistemologia Biológica. Trad. de F. Sardo e S. Dias. In: J. Piaget (org.) Lógica e Conhecimento Científico, vol. 2, pp.255-81. Porto: Livraria Civilização.

Rodis-Lewis, G. 1984. Descartes. Paris: Le Livre de Poche.

Rose, S. 2007. Qual é o Sentido da Vida? Trad. de M. J. Figueiredo. In: H. Swain (org.) Grandes Questões Científicas, pp.357-63. Lisboa: Gradiva.

Ruse, M. 2002. O Mistério de Todos os Mistérios. Trad. de A. P. Tanque e M. H. Serrano. Vila Nova de Famalicão: Edições Quasi.

Shapin, S. 1999. A Revoluçẫo Científica. Trad. de R. Roque. Algés: Difel.

Soromenho-Marques, V. 1998. O Relógio Vivo. O Pensamento Biológico e a Herança Cartesiana. In: L. R. Santos et al. (orgs.) Descartes, Leibniz e a Modernidade, pp.415-26. Lisboa: Edições Colibri. 
Sulston, J. 2007. Poderemos Acabar com as Doenças? Trad. de M. J. Figueiredo. In: H. Swain (org.) Grandes Questões Científicas, pp.257-9. Lisboa: Gradiva.

Thom, R. 1985. Parábolas e Catástrofes. Trad. de M. Brito. Lisboa: Publicações Dom Quixote. Veloso, A. M. 1982. Do Pensamento à Comunicação: o Problema da Inter-relação na Filosofia Cartesiana. Revista Portuguesa de Filosofia 38(4): 241-54.

Warnock, M. 2007. Teremos o Direito de Interferir na Natureza? Trad. de M. J. Figueiredo. In: H. Swain (org.) Grandes Questões Científicas, pp.239-44. Lisboa: Gradiva.

Weber, M. 2017. A Política como Vocação/A Ciência como Vocação. Trad. de A. Morão. Silveira: Bookbuilders.

\section{Notas}

${ }^{1}$ Da esfera da produção à da reprodução, são inúmeros os exemplos. (De uma e outra, talvez os mais paradigmáticos sejam os alimentos transgénicos e a clonagem.) Além do conteúdo dos mesmos e da sua enumeração, o que impressiona o vulgo, à escala mediática, passa necessariamente pela dimensão "omnívora" dos seus efeitos sociais.

${ }^{2}$ Claro que os biólogos contemporâneos rejeitariam tal crise, reduzindo-a a uma mera especulação filosófica, tanto mais que eles "julgam não ter necessidade de teorias" (Thom 1985, p.57).

${ }^{3}$ Quarenta anos depois, não nos parece que o diagnóstico, na realidade, tenha perdido actualidade e pertinência.

${ }^{4}$ No que diz respeito a esta interpretação da filosofia clássica, não se veja no platonismo um contra-exemplo. Com efeito, embora muitas Histórias da Filosofia classifiquem Platão como um idealista, trata-se de um despropósito, pois devemos reconhecer na sua Teoria das Ideias um realismo metafísico. Nele, como é sobejamente sabido, as Ideias não constituem representações mentais: estamos perante entidades cuja valência ontológica é máxima. Além do que, enquanto posição filosófica, o idealismo só surge com Descartes, ainda que neste o mesmo se situe num plano metodológico, coabitando, aliás, com um realismo crítico.

${ }^{5}$ Desta assunção, sem dúvida, a afirmação mais vigorosa e impressionante encontra-se no famoso passo do Leviatã de Hobbes, no qual o filósofo inglês reduz as operações da razão à subtracção e à adição (1988, p.27). Muitos defensores das ciências cognitivas vêem nela, aliás, uma antecipação notável da chamada "teoria computacional da mente".

${ }^{6}$ Não espanta, pois, que um ilustre defensor da ciência — e feroz opositor da religião considere o porquê de todos os porquês ("Por que razão existe alguma coisa em vez de nada?") uma "questão existencial vazia" (Dawkins 2002, p.108).

${ }^{7}$ A posse de uma vontade livre não carece de prova, porque dela temos um conhecimento imediato e indubitável (Descartes 1978, pp.85-6).

${ }^{8}$ Trata-se de uma pergunta que corresponde precisamente ao título do artigo em questão, no qual, curiosamente, nunca aparece o nome de Descartes.

${ }^{9} \mathrm{O}$ acontecimento fundamental do nosso tempo, a globalização, resulta da generalização, à escala planetária, do modo de produção do Ocidente. Para a sua sobrevivência, de cuja sustentabilidade ecológica podemos duvidar, é indispensável o consumo desenfreado de combustíveis fósseis. Daí que a busca do seu controlo económico, fonte de poder, defina os contornos da actual geopolítica. 
${ }^{10}$ Para Hegel, tanto Sócrates como Descartes, por terem dado origem a viragens radicais da Filosofia (antropológica, no caso do primeiro; gnosiológica, no do segundo), merecem o título de "heróis do saber". Serão o equivalente, no plano do pensamento, dos grandes "homens de acção": Alexandre, César e Napoleão.

${ }^{11}$ A complexidade dessa transição remete-nos imediatamente para o problema da origem da vida: "Que características são, pois, indispensáveis para que a não-vida se torne vida? Também esta questão não é de fácil resposta: exactamente porque não há uma transição clara de 'não-vida' para 'vida'. [... ] A transição entre o desvitalizado e o vitalizado também se manifesta, ainda hoje, na existência de estados intermédios" (Eigen 1990, p.122). Como exemplo desses estados intermédios, o Autor refere a existência dos vírus: quando são cristalizados, assemelham-se às substâncias minerais; incorporados, porém, nos organismos hospedeiros, comportam-se como seres vivos (Eigen 1990, p.122). Mas sê-lo-ão, de facto? A verdade é que, fora do hospedeiro celular, são absolutamente incapazes de reprodução independente, a qual constitui a característica essencial da vida.

${ }^{12} \mathrm{~A}$ crítica cartesiana à busca de uma explicação teleológica, que diz respeito à quarta das quatro causas, para o Estagirita, não deve obscurecer a ideia de que o filósofo grego, ao contrário do que poderíamos deduzir de uma leitura apressada do excerto acima citado, nunca quis atribuir intenções a Deus, de cuja natureza afirma o carácter impessoal. (Como é do conhecimento geral, a concepção de uma criação do mundo não faz parte da tradição clássica, sendo, sim, uma característica particular da cultura judaico-cristã. É por isso que, por oposição ao Deus omnipotente do filósofo gaulês, o de Aristóteles, na sua qualidade de Motor Imóvel, não cria a realidade, mas tão-somente a põe em movimento.) A chamada "causa final" serve-lhe apenas para destacar a função de múltiplas actividades e estruturas, que ainda hoje, aliás, depois de Darwin, continua a ser o motivo da investigação de muitos biólogos contemporâneos. Além do que, ao invés da cinemática do pensador francês, a física peripatética é uma ciência geral da mudança, da qual o movimento local, como sabemos, representa apenas uma modalidade espacial.

13،Por detrás da pergunta está sempre implícita, mas nunca justificada, a implicação de que se a ciência é incapaz de [lhe] responder [...], então deve haver outra disciplina qualquer que está qualificada para [o efeito]. Claro que a implicação é bastante ilógica" (Dawkins 2002, p.108). Mas é também ilógico, claro está, desqualificar a questão, como o faz o cientista britânico, pelo simples facto de a ciência não ser capaz de lhe dar uma resposta.

${ }^{14}$ Este escritor francês, cuja fidelidade a Descartes parece ter sido periclitante nos últimos anos da sua longa vida (1657-1757), chegou a ser secretário perpétuo da Academia das Ciências.

15 “O relógio foi o modelo mais apelativo para muitos dos filósofos modernos, o escolhido de entre todas as construções mecânicas cujas características poderiam servir de modelo ao mundo natural. De facto, seguir a metáfora do relógio para a natureza através da cultura europeia do princípio do período moderno permite desenhar os principais contornos da filosofia mecanicista e, dessa forma, acompanhar muito do que tem sido tradicionalmente entendido como central à Revolução Científica" (Shapin 1999, p.52). Entre as virtudes heurísticas deste modelo, devemos salientar dois aspectos complementares: por um lado, o relógio, pela complexidade das funções que lhe cabem, parece imitar o comportamento intencional de seres inteligentes; e, por outro, pela regularidade dos seus movimentos, manifesta uma estrutura totalmente inteligível (Shapin 1999, pp.55-6). O modelo mecânico permite sustentar, por 
conseguinte, a rejeição moderna da diferença, que Aristóteles estabelecera, entre arte e natureza. Peca, porém, por não conseguir responder às exigências de compreensão dos fenómenos orgânicos.

16“O que é considerado relevante é o crescimento orgânico entendido como alargamento por expansão e agregação. O problema reside em compreender a intensificação material no quadro de uma mesma estrutura, e não tanto em compreender a génese das estruturas e as mutações internas e qualitativas no seu processo de transformação e crescimento" (Soromenho-Marques 1998, p.418).

${ }^{17}$ Para a ilustração dessa assimetria, vejamos o seguinte exemplo: "A mão tem uma forma característica, mas não é feita de células com forma de mão, como aconteceria se os fenótipos crescessem como os cristais" (Dawkins 2002, p.164).

${ }^{18}$ De resto, contrariamente a Kant [cf. §75 da Crítica da Faculdade do Juízo (1790)], o próprio Cuvier, em 1825, defendeu que seria possível, no futuro, o advento de um "Newton da História Natural": "sem dúvida que os astrónomos avançaram mais do que os naturalistas [...]; mas, depois de Anaxágoras, veio Copérnico e Kepler, que abriram caminho a Newton; e por que razão a História Natural não terá também, um dia, o seu Newton?” (cit. por Le Guyader 1984, p.80).

19 "Foi ele quem inventou o termo Biologia, [que] quer dizer o conceito segundo o qual tudo o que é vivo é animado por uma mesma lógica" (Allègre 2005, p.284).

${ }^{20} \mathrm{O}$ mesmo poderíamos dizer, mutatis mutandis, da actual visão computacional da mente.

${ }^{21}$ Embora a ideia não esteja expressa neste excerto, encontra-se em toda a obra cartesiana.

${ }^{22}$ Embora constituam possíveis, metafisicamente falando, porque a sua concretização não deixa de estar ao alcance de Deus, certo é que, para Descartes, os andróides, do género daqueles que se dão a ver, por exemplo, em Blade Runner (1982) - celebérrimo filme de Ridley Scott —, são por ele concebidos como algo bastante inverosímil.

${ }^{23}$ Todo o extracto, acima citado, do Discurso do Método pode ser lido como uma reacção à defesa, por parte do céptico francês, da existência de uma inteligência animal. Veja-se, por exemplo, o seguinte passo da Apologia de Raymond Sebond: "Não podemos tão-pouco afirmar que os animais são incapazes de se instruir como nós, homens. Ensinamos os melros, as pegas e os papagaios a falar. E com tanta facilidade se ajeita a sua voz aos sons que lhes ensinamos, às sílabas que lhes comunicamos, que é evidente a existência neles de um processo de raciocínio" (Montaigne 1991, p.213).

${ }^{24}$ Para a indústria agropecuária, por exemplo, que é uma vaca? Uma fábrica de carne e leite! E neste domínio, claro está, os conhecimentos científicos servem apenas para aumentar os seus índices de produção.

${ }^{25}$ Para Veloso (1982, p.253), se Descartes tivesse escrito uma Meditação Sétima acerca da linguagem, teria trazido uma solução para a pergunta acima enunciada. Não somos da mesma opinião, porque estamos perante um problema estrutural da filosofia cartesiana.

${ }^{26}$ Devemos notar que, em Descartes, temos, no fim de contas, uma noção equívoca de substância, residindo aqui, talvez, a deficiência insuperável da sua metafísica.

${ }^{27}$ De uma carta datada de 28 de Junho de 1643, é de transcrever aqui, pela sua importância, o trecho que se segue: "[... ] et enfin, c'est en usant seulement de la vie et des conversations ordinaires, et en s'abstenant de méditer et d'étudier aux choses qui exercent l'imagination, qu'on apprend à concevoir l'union de l'âme et du corps" (cit. por Rodis-Lewis 1984, p.366).

${ }^{28} \mathrm{~A}$ teleonomia estará para a teleologia assim como a astronomia está para a astrologia 
(Papert 1981, p.193).

${ }^{29}$ De algum modo, o título é enganador. Na verdade, se o tomássemos à letra, teríamos de procurar, em Darwin, uma solução para o problema da origem de todas as espécies, o que seria um esforço vão. Com efeito, o mecanismo da selecção natural, que constitui o argumento central da obra, apenas é capaz de explicar o modo pelo qual uma nova espécie pode surgir, por força da pressão evolucionária, de uma outra, mais antiga. Fica de fora do âmbito da explicação, por consequência, o fenómeno original da emergência das próprias espécies, no seu todo, ou seja, o princípio da vida.

${ }^{30}$ Divergindo deste Autor, porém, quanto à putativa influência malthusiana, há quem afirme, em conformidade com a perspectiva de Ernst Mayr, que "nada está provado" (Allègre 2005, p.287). Seja como for, parece-nos muito difícil negar a existência, pelo menos, de um efeito catalisador, em Darwin, da leitura de Malthus.

${ }^{31}$ Assumindo, sem complexos, a intencionalidade política do seu discurso, o Autor, cuja crítica sociológica de cariz marxista tem em vista, e de uma forma pertinente, a desmistificação do trabalho dos cientistas, ilustra a denúncia com o exemplo darwiniano: "Apesar de pretender estar acima da sociedade, a ciência, tal como a Igreja antes dela, é uma instituição social por excelência, reflectindo e reforçando os valores dominantes e visões da sociedade em cada época histórica. Por vezes, a origem de uma teoria científica na experiência social e o modo pelo qual essa teoria científica se assume como uma tradução directa da experiência social são completamente evidentes, até mesmo a um nível minucioso. O caso mais famoso é o da teoria da evolução por selecção natural de Darwin" (Lewontin 1998, pp.28-9; é nosso o grifo).

${ }^{32}$ A este respeito, cf. "teses ultramaterialistas de Gould" (Changeux e Ricœur 2001, p.182).

33 "Mais ce serait une grave erreur de vouloir trop se concentrer sur les aspects numériques du fonctionnement génétique, et de négliger la nature fondamentalement analogique de la chimie qui sous-tend tout ce processus" (Keller 2004, pp.36-7). Quanto à avaliação da pertinência deste alerta epistemológico, basta atentar na crítica de René Thom (1985) à Biologia Molecular.

${ }^{34} \mathrm{~A}$ acção das proteínas é fundamental, porque, agindo como enzimas, alteram as substâncias químicas. Por exemplo: uma delas transforma a tirosina, um aminoácido que se encontra em diversos alimentos, em dopamina, mediador químico indispensável à actividade normal do cérebro e que pode fazer que nos sintamos activos e excitados. Segundo Dawkins, "poderíamos ver uma enzima como uma grande ferramenta mecânica, cuidadosamente calibrada para ter como resultado uma linha de produção de moléculas com uma forma determinada" (2002, p.36). Dando o devido peso aos itálicos (da nossa responsabilidade), daqui resulta uma imagem muito particular do ser vivo, que o assimila a uma autêntica fábrica química.

${ }^{35}$ Donde a complexidade da noção de gene, cuja definição, seguindo o seu uso pelos especialistas em Biologia Molecular, não é, curiosamente, unívoca (Keller 2004, pp.30-1). É por isso que, paradoxalmente, a resposta à pergunta "Quantos genes, no fim de contas, possui o genoma do ser humano?" depende, segundo a epistemóloga norte-americana, da natureza da definição de que nos estejamos a servir.

${ }^{36}$ Ultimamente, porém, assistimos à crítica deste "dogma" da Biologia Molecular, que nos diz que apenas contribuem para a formação do organismo os genes inscritos no ADN humano (cerca de vinte e cinco mil), sendo inútil o resto do genoma. Afinal, parece que, em conformidade com os recentes avanços nesse domínio, quase todo ele, no atinente ao cumprimento 
do programa genético, tem um papel a desempenhar.

37 "Quando nos referimos aos genes como capazes de se replicar a si próprios, dotamo-los de um poder misterioso e autónomo que os parece colocar acima dos materiais mais comuns do corpo. Todavia, se é possível dizer-se que existe algo que se replica a si mesmo não será o gene, mas todo o organismo como um sistema complexo" (Lewontin 1998, p.77).

${ }^{38}$ Desta via, curiosamente, o ácido acetilsalicílico (vulgarmente conhecido pela marca comercial de origem: a aspirina) continua a ser o grande marco, que data de há mais de cem anos, e cuja aplicação clínica mantém todo o seu largo espectro. Isto também diz muito do que, para alguns, são os sinais de esgotamento deste meio de produção de medicamentos.

${ }^{39}$ A propósito desta variação, é de realçar o impacto que teve na imprensa generalista o anúncio, pela revista Science, em Dezembro de 2007, do "avanço científico do ano": a chamada "genómica pessoal" (cf. Público. 2007. Dez. 21, p.20).

${ }^{40}$ Desta obra de divulgação da Biologia Molecular, basta que se diga, para a retratar, que é deveras representativa do que há de pior na abordagem reducionista, quando ela extravasa os seus limites metodológicos. - Em relação a um dos seus autores, Dean Hamer, geneticista norte-americano, podemos dizer que se tornou famoso, quando publicou, em Julho de 1993, na revista Science, um artigo com um título apelativo: "Uma Ligação entre os Marcadores do ADN no Cromossoma X e a Orientação Sexual Masculina". A especulação mediática que se lhe seguiu não deixa de ser mais um exemplo, no âmbito da manipulação da opinião pública, das "relações perigosas" que hoje envolvem cientistas, jornalistas e políticos.

${ }^{41}$ Segundo Lewontin, a ciência, enquanto principal força de legitimação do mundo ocidental, tem assumido, do ponto de vista institucional, a mesma função que cabia, na Idade Média, à religião (1998, pp.26-7). — Para a compreensão da influência recíproca que se verifica entre ciência e política, veja-se também Thom (1985, pp.20-4).

${ }^{42} \mathrm{Da}$ indústria farmacêutica às companhias de seguros, é fácil imaginar o impacto social da mercantilização da informação genética de cada um de nós. Os riscos não são de somenos, tanto no atinente à violação da privacidade dos dados pessoais como em relação à democratização do acesso aos cuidados de saúde.

${ }^{43}$ Em relação a outros contextos (cf. n. 1), parece-nos um pouco datada a intervenção de René Thom, devendo, pois, ser refreado o seu pessimismo.

${ }^{44}$ Para a razão de ser desse desfasamento e a avaliação do seu impacto na ciência, de um ponto de vista ético, veja-se Morange (2005, pp.206-7).

${ }^{45}$ Veja-se a crítica de Blackburn a Dawkins: "As pequenas mudanças ocorrem nos genes, os quais se multiplicam então, e os índices de sobreviventes não-arbitrários são indicadores da aptidão relativa dos genes e dos alelos nos seus ambientes específicos. Contudo, do facto de um organismo ser de um tipo que teve de ter sobrevivido e evoluído não podemos inferir, de todo em todo, que não tem de se preocupar com coisa alguma além da sua própria sobrevivência ou do seu 'interesse' próprio ou do número da sua própria prole ou de qualquer outra coisa individual. A inferência que parte de uma característica funcional e conclui uma característica típica é simplesmente falaciosa" (2018, p.27; grifo nosso).

46“Conhecemos os graves desvios da biologia e, muito particularmente, da genética, em benefício de ideologias de exclusão que conduziram ao racismo e ao genocídio" (Changeux e Ricœur 2001, pp.20-1).

${ }^{47}$ Trata-se de um problema que, paulatinamente, vai conquistando uma crescente visibilidade social. Disso mesmo é sintoma, de resto, o facto de a imprensa generalista acolher cada 
vez mais, nas suas páginas, debates sobre a matéria (cf., v.g., Gall, E. e Testart, J. 2007. Pour une Science Citoyenne. Le Monde. Set. 27).

${ }^{48}$ Esta afirmação galileana anuncia a radical separação entre ciência e filosofia, de que hoje, de resto, estamos em condições de avaliar os efeitos, positivos e negativos, tanto epistemológicos como institucionais.

${ }^{49}$ Nenhuma delas, aliás, se caracteriza por um enquadramento matemático, o que nos permite levantar a vexata quaestio das tradicionais dificuldades dos biólogos com a Matemática, de que nos fala René Thom (1985, p.57). Opondo-se-lhe, porém, o neurobiólogo Changeux, em diálogo com o matemático Alain Connes, considera que a razão de ser dessa dificuldade se prende com a própria natureza do conhecimento biológico: "O relacionamento das estruturas com as funções é a via real para a descoberta [em Biologia], e não simplesmente a descrição de um processo por uma equação matemática" (1991, p.91). Na mesma linha — kantiana - de pensamento sobre o ser vivo, e sob o pano de fundo de uma comparação com a Física, Ernst Mayr, em 1982, pôs o problema, julgamos nós, nos seus devidos termos, distinguindo, pois, o perfil epistemológico do trabalho do biólogo: "Instead of formulating [deterministic] laws, biologists usually organize their generalizations into a framework of concepts" (cit. por Le Guyader 1984, p.80).

${ }^{50}$ Mesmo assim, no que toca aos processos metabólicos que regulam os organismos, René Thom, de uma forma audaz, não deixa de "afirmar que, paradoxalmente, eles eram mais bem conhecidos antes da descoberta do $A D N$ e das moléculas químicas que caracterizam o genoma, com a excepção de certos casos, muito particulares, muito locais" (1985, p.65; é nosso o grifo).

${ }^{51}$ Mesmo um crítico acerbo da metodologia reducionista, como é o caso de René Thom, não pode deixar de lhe reconhecer eficácia (1985, p.111).

${ }^{52}$ Para lá do jogo de palavras, importa reter o mais importante, ou seja, a consciência dos riscos que são intrínsecos à moderna exploração (no duplo sentido do termo) da Natureza, cujo desequilíbrio ecológico é hoje não só um dado adquirido, mas uma notícia corrente e planetária.

${ }^{53}$ Expressão de que se servem, para designar o homem, alguns comentadores cartesianos (Changeux e Ricœur 2001, p.35).

${ }^{54}$ Como exemplo maior e contemporâneo dessa ausência de pensamento acerca dos entraves que se colocam à articulação dos planos científico e fenomenológico, temos a citação que se segue: "A ciência emergente da Biologia Molecular fez descobertas desconcertantes que nos demonstram, sem sombra de dúvidas, que os genes são o factor mais importante que distingue uma personalidade de outra" (Hamer e Copeland 1998, p.20; é nosso o grifo). Veja-se também a denúncia heideggeriana do "erro do biologismo": "O facto de a Filosofia e a química fisiológica poderem examinar o homem como organismo, sob o ponto de vista das Ciências da Natureza, não é prova de que neste elemento 'orgânico', isto é, de que no corpo explicado cientificamente, resida a essência do homem" (Heidegger 1985, p.47). 